\title{
I ハブの生態研究と駆除対策
}

\section{1. ハブの生態研究と駆除対策}

田中宽（東大・医科研・寄生虫）

わが国におけるハブの生態研究はすでに20年以 上前から始まっており, 高良, 木場の単行本はす でに1962年に発表されている。乙の時代は生物学 あるいは博物学的研究が主体をなすが, その後, 室内あるい络野外でのハブの行動の研究（田中, 1967）をはじめ，奄美大島では昭和45年度より系 統的なグループ研究が始まり, 昭和52年度からは 沖縄県と奄美群島でハブの駆除法を目標にした生 龍研究が桩大されて行われるに至った。これらの 研究の進展は, 我々にとっては当然のととに受け 止められているが, 毒へビ 1 種について梁く生 物・生態学的研究の行われたものは世界に類がな く，1980年 8 月に那霸市で開かれた毒へビ咬症の 国際セミナーで注目を集めた。

本シンポジゥムでは, かなりまとまった研究成 果住き，その主たる研究者敒発表してあらうが, その他の注目すべき二・三の点を指摘しておく。

八ブの生息密度の測定は, 1970年に連続捕獲法 で行われ, 奄美群島で 5 匹/ha 以下, 平均で 3.16 （田中ら，1974）とされているが，その後の研究 による補正ではその 2 倍の密度が推定される。八 ブ咬症発生と環境の関係の解析で, 奄美群島では 部落別に咬症発生数をみると, 実際使作してい る経営耕地面積と密な関係があった（田中ら， 1978)。乙の法則は沖縄で成立するとは考えられ ず，地域毎の検討が必要であろう。ネズミの密度 が高い程, ハブ密度は高く（和田ら, 1981）, ネズ ミの密度低下は八ブ密度の低下につながる（池田 ら，1971）という報告があるが，八ブ駆除がネズ ミの増加につながる可能性があり, 相互関係をさ らに検討する必要がある。

ハブの誘引効果は, 沖縄におけるヒヨコの実験, 奄美におけるネズミを人れた捕獲箱を用いた実験
（林ら，1979）により証明されたが，さらに生理・ 生態学的な室内検定法を確立し, 誘引物質の究明 を行う必要があり, 将来の最む重要課題であろ う。

\section{2 電波追跡によるハブの行動研究}

和田 芳武 (東京女子医大・寄生虫)

ハブの行動を電波探知によって追跡するための 小型の UHF 発信器が開発され（池田ら，1971) てから，1979年まで徳之島，奄美大島の野外で害 験を続けて来た。計45匹のハブを用いたが，内29 匹では野外での自発的行動観察を, 残りの16匹で は砂糖キビ刈取作業中の人間の活動に対する反応 を観察した。ハブに発信器を取付けるには, 初期 は切開手術による植込みを行ったが，中期からは 粘着テープで体表に巻き付けた。

自発的行動に関しては，下記の結果が得られた。 八ブの活動は明らかに夜間に活発であるが，日中 亿移動する事ああり，一晚中ほとんど移動しな いとともあった。夜間の活動は，通常 1-2 時間 動くと 1-2 時間停止するといった具合で一晚中 動き続ける事は極めて稀であった。5-10分毎の 観察でみると, 移動速度は最高で $3 \mathrm{~m} /$ 分, 通常 $1 \mathrm{~m} /$ 分以下であった。詳細に連続探知が続けられ た延15例について，一晚に動いた範囲をカバーす る门の直径を取ってみると, 雌は 6 例の平均で 30 $\mathrm{m}$ 弱, 雄 9 例で平均 $44 \mathrm{~m}$ 強であり, 雌は狭い範 囲内を動き回る事が多く, 雄はより直線的に長距 離を移動する例がよく見られた。前記の平均値に は算人してないが一晚の最大移動距離は直線で $320 \mathrm{~m}$ というのが雄で記録された。また八ブは水 に人ると移動が速く, 行動半径も大きくなる傾向 があった。1 週間の観察から,一旦好適な日中の 隠場所を見つけた八ブは, 数日間はその場所を中 心に動いて居り, あたかむ行動圈を持つ様に見え た。観察終了後29匹の内12匹が木の根の下をはじ 
め土中の隙間や穴から，11匹が濃密な茂みの中か ら回収された。

砂糖キビ生産組合によるキビ刈取りの際のハブ の反応については以下の通りである。はじめに 1-2名がキビ畑に人り，キビの梢頭部切落作業 を行うが，この作業は人の移動が速い。この作業 者の接近で逃げるハブは 2 例/ 10例であり，逆に

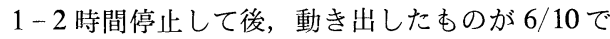
あった。この 6 例は人の速い接近で逃げる前に人 が踏越えたため，攻撃体勢を取って停止していた とも考えられる。キビの切倒作業はかなりの人数 でゆっくりと前進するが, この作業者の接近であ 2 月には $3 / 5$ が逃げずに発見捕獲された。しかし 4 月になると， $5 / 6$ が数 $\mathrm{m} \sim 10 \mathrm{~m}$ 逃げた。結果と して 2 月には $1 / 4 か ゙ ， 4$ 月には 3/5〜5/7と半数以 上が刚取中に捕獲されず，畑の外に逃亡した。

\section{3 ハブ生息の地域分布について}

吉田 朝啓

(沖䋲県公害衛研)

赤領 博行

(沖縄公衛協会)

毒蛇問題への対応策として, 抗毒素による咬症 患者治療体系の確立が優先されているが, 根本的 な対策としては，八ブと人間の生活圈を人為的に 分離して双方の接触を防止することが，またすす められる。

現在沖縄県では年間 200 名余の咬症患者が発生 しており，そのおよそ70\% は農村集落内外及び 都市内住宅地周辺での事例で占められている。そ こで，都市と農村におけるハブの生息分布を調べ る手法を考案し，分布の様相を知るために，那䩗 市 (人口 30 万人, 面積 $38 \mathrm{~km}^{2}$ ), 西原町 ( 1 万 6 千人, $\left.15 \mathrm{~km}^{2}\right)$, 佐敷町 $\left(1\right.$ 万人, $\left.10 \mathrm{~km}^{2}\right)$ で害 態調査を行った。

那龩市で85,000世帯中8,779世帯（約10\%），西 原町で 3,824世帯中 1,256世帯（約33\%），佐敷町 で全 2,384世帯を戸別訪問し，居住歴 5 年以上の 成人に対して最近 5 年以内に目撃した蛇類の種 別・場所・年月について聞き取りを行い，脱皮・ 卵を含む総数でそれぞれ 2,265件，439件，455件 の目撃頻度を得た。これを地図化した目撃分布図 と植物分布図 - 原色航空写真との照合, 現地踏查
によりハブの生息分布を示す現況図が得られたが， その中，那羁市内の孤立したハブ生息地が29区， 延面積が 185 ha, 道路によって分断された生息 地12区，383 ha，他の市町村に連続している部分 11区， 856 ha が明示された。この現況図によれ ば，那䩗市で 全市域の $45.3 \%$ 占める ハブ生息 地に28,096世带 $(32.3 \%$ ，約 100,000 人)，西原町 では 90.9\%の 生息地に 3,190世帯（83.4\%，約 16,000 人)，佐敷町では $80.9 \%$ の生息地に 1,437 世 帯 $(60 \%$ ，約6,000人）が住んでいることになる。

また那霸市内のハブは 1,189件中 $98 \%$ は林・草 地の辺縁から $30 \mathrm{~m}$ 以内で目撃されており, 佐敷 町, 西原町の農業地帯でも $95 \%$ 以上が $50 \mathrm{~m}$ 以内 で目撃されていて，八ブが草木に大きく依存して いる傾向がうかがわれた。

さらに那霸市内の 2 車線道路の夜間 (9:00 p.m.5:00 a.m.) の交通量から車間距離・車間時間を求 めると, 最む車の少ない道路で27秒間隔となり, 市街地で $13 \mathrm{~m}$ 道路 ( 2 車線) の両側の住宅地を含 む 40〜 50m の距離をハブが横断して他の林・草 地に移動する可能性は極めて小さいことが推定さ れた。

一方, 典型的な沖縄の農村と思われる佐敷町で, 全域に $100 \mathrm{~m}$ の方形区画を設け, 目撃頻度と世帯 数との関係をみると，1世帯当たりの目撃率は世 帯数の増加につれて減少し, 1 ha 当たり 25 世帯の ほぼ飽和状態でハブの目撃が 0 に近づくことがわ かった。

これらのととから，都市でも農村であハブの分 布は大きく林・草地に依存し，それが住宅地に よって包囲された状態では辺縁から僅か $50 \mathrm{~m}$ 以 内に移動が限られ，さらに単位面積当たりの住宅 が増えるに従って生息分布は 0 に近づく様相が理 解できる。また，乙れらの実態を把握するのに， 户別訪問による分布調査は有用な手段であると判 断された。

\section{4 水納島におけるハブの生態研究と駆除} 勝連 盛輝, 吉田 朝啓 （沖縄県公害衛研）

ハブ駆除の手法は，人手による直接捕獲の他に， 
トラップ，接触殺蛇剂，天敵，ヘビアメーバ，八 ブ探索犬などが研究されてきており, 現在む進行 中である。我々は，環境污染，生態系の攪乱の可 能性の最む少ない方法として，トラップによる除 去法により, 分布, 密度, 個体群動態, 食物連鎖 に関する生態研究と，ハブの完全駆除を目的とし て，1957年より，沖縄県水納島でハブ駆除実験を 行っている。水納島は長径 $1 \mathrm{~km}$ 標高 $12 \mathrm{~m}$, 面積 約 50 ha の小島で約 50 人の住民が住む。外周をモ クマオウとアダンの防風林でおおわれ，中央部は 畑と牧草地で一角に約15軒の集落がある。同島に はハブの天敵が生息せず，他の地域ではハブの主 要な慨であるネズミ類も生息せず，動物層は比較 的単純である。小鳥やトカゲの数は極めて多く， ハブの主要な慨となっている。調查方法は，島全 面に $50 \mathrm{~m}$ 間隔で, 185個のトラップを設置し, 毎日または隔日点検した。調査は 4 月-11月まで 行ったが，年により異なる。各年の調査日数，1 日 1 罠当たり捕獲数は，1977年一114日・43匹・2

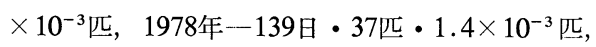
1979 年一 123 日 .51 匹 $2.2 \times 10^{-3}$ 匹，1980年一 229 日・40匹・0.9 $\times 10^{-3}$ 匹，1981 年-229日・20 匹・0.5 $\times 10^{-3}$ 匹, 減少してきている。 5 年間 の捕獲総数は雄 96 , 雌91, 不明 5 の192匹で性比 は 1:1である。防風林, 畑・草地での捕獲が多 く, 砂浜, 住宅地で少ない。畑・草地での昼間の ハブ目撃は稀なので，防風林とともにハブの主 要な餌場となっていると考えられる。捕獲ハブの 全長は $75 \mathrm{~cm} \sim 150.5 \mathrm{~cm}$ である。他の地域では $200 \mathrm{~cm}$ 前後まで成長する事から，同島のハブは 小型といえる。また，孵化直後のハブの大きさは $30 \mathrm{~cm}$ 前後であり, 孵化後 $1 ・ 2$ 年はトラップに 捕獲されることを示し, 幼蛇は誘引䬣のヒヨコを 捕食しないむのと考えられる。香村 (1980) の “ハブの実験室内飼育”の飼育下のハブの体長に 準じて作成した捕獲ハブの生命表によれば，1977 年の同島のハブ数は雄 74 , 雌59, 計 133 となる。 1978年は雄74・雌56・計130, 1979年雄61・雌46・ 計105と, ほとんど変化しないが, 1980年一雄27・ 雌 24 ・計 56, 1981年一雄 7 ・雌 16 ・計 23と減少し ている。トラップによる除去効果が 3 年間殁ど表
われないのは，幼蛇が捕獲されないことに起因す る。実数は自然死やトラップに捕獲されない個 体を加えることにより多少増えるが，4 年目以後 の, 推定総数の減少, 捕獲効率の低下，また平均 体長の低下などから，同島のハブ個体群の縮少は 明らかであり, 数年以内のハブの完全除去が期待 される。

\section{5 電気柵を用いたハブの侵入防止 林良博（東大・医科研・寄生虫）}

八ブ咬症において注目すべきことは，その大半 が家敷内 $(20 \%)$ と耕地内 $(60 \%)$ で発生しているこ とである。一方，奄美大島及び徳之島の家敷・耕 地面積は全島面積のそれぞれ $5 \%$ 及び25\%にすぎ ない。このことは林野をハブ駆除の対象から除い ても，人家及び耕地のハブ生息数を激減させ，そ の再侵人を防止することができるならば，咬症数 を著しく減少させることができることを示唆する あのである。長期的な観点からハブの駆除を行う には, 環境整備によるハブの生息適地の撤去が もっとも抜本的方法であるととに疑う余地はない。 しかし環境整備を進めるに際して 2 つの問題点が ある。第一は面積当たりの費用が高く, 短期間に 㕕域で十分な効果をあげることが困難である。第 二に，環境整備が時として環境の污染を招く，あ るいは住民にとって生活しづらい人工的な環境を 増やすととになる恐れがある。電気棚はこうした 問題点を解決するために開発が進められた。室内 実験で明らかになったのは以下の 2 点である。1) 500 オームの負荷で波高值 $480 \mathrm{~mA}, 0.31 \mathrm{mQ}$, 周期 約 1 秒の高電圧パルス電流を用いると, 全長平均 $140 \mathrm{~cm}$ のハブは $50 \mathrm{~cm}$ 以上の高さの㥊を越える ことができない。2）電気ショックを受けたハブ は，それを記憶するイノシシなどの高等な動物と 異なり，何度も梱を越えようと試みた。乙れは柵 が完全に，しかも永続的に設置されない限り，八 ブの侵人が起こりうることを示唆するむのである。 一力, 奄美大島の手安部落 $(6.75 \mathrm{ha})$ 飞設置した $1,000 \mathrm{~m}$ の電気柵による野外実験では, 設置前の 半数以下のハブが柵内で観察されるにとどまった。 現在, 徳之島の 3 部落に合計 $7,000 \mathrm{~m}$ 以上の電 
気柵を設置して，本格的な野外実験を行っている。 このなかで注目される二・三の点をあげると，1) 管理の簡素化をはかるために電源として太陽電池 を用いているとと。2）電気的なトラブルを減ら すために金属製品をさけグラスファイバー製品を 多用しているとと。3）八ブの侵人防止効果にと どまらず，積極的に捕獲するトラップ機能をむつ 電気柵を用いている等である。

\section{6 奄美群島におけるハブ駆除対策} 三島 章義 (獨協医大・医動物)

奄美群島の ハブ生息地では，例年 ハブ咬症の 55\%以上が耕作地で発生しており，てれについで 人の居住区すなわち集落内が $25 \%$ 前後を占めてい る。従って奄美群島のハブ咬症を減らすには，住 民の日常生活に密接したてれら耕作地帯と集落内 におけるハブ咬症の発生を防止するととが重要な 課題である。

そこで国土庁と鹿児島県は, 奄美群島振興開発 事業の一環として, 昭和 52 年度から 3 年間, 基礎 的なハブ駆除対策調查研究を推進した。調査と実 験的研究は, 八ブの生態・疫学研究に関係してい た研究者を中心にハブ駆除対策研究会を組織し, ハブ駆除に関する基本的なハブの生態や駆除方法 の研究開発を行った。

てれらの調查研究では, ハブの出現頻度の高い 場所や生息状況が明らかにされ，特に集落内では 屋敷の境界構造をなす石垣や土手の多い場所が, 八ブの出現頻度の高いととが判明した。また電気 柵を使ったハブ防除網が，ハブの侵人防止に有効
であり，ネズミを㧍とりにしたハブ捕獲器の有効 性も確認された。

昭和 55 年度からは, 乙れらの研究成果をむとに して, 総合ハブ駆除モデル研究を推進している。 本研究は 1) 捕獲器によるハブの誘引捕獲実験 と誘引物質の研究開発，2）電気梱によるハブの 侵人防止実験，3）八ブの主要食物であるネズミ の駆除実験，4）八ブの生息所となる石垣や土手 を撤去し, ブロック塀やコンクリート推壁に改善 する環境整備実験などの 4 項目について実験を進 めている。

55 年度は人家の密集した徳之島町手々地区， 56 年度は人家と耕作地が混在する同町轟木地区を実 験区とした。実験は, 周辺地域から実験区内への 八ブの侵人を防止しながら, その中のハブを駆除 し，ハブの生息所となる石垣や土手を撤去改善す るという方法をとった。すなわちてのような方法 によってハブの生息個体数を隇らす努力と, ハブ の生息環境を変えることによってその生息密度を 下げ，さらに集落内および屋敷内へのハブの再侵 入を防止しょうとするものである。

これらの実験で, 電気柵のハブ侵人防止効果, ハブトラップの捕獲率は人力によるハブ狩りより あ高く, 有効であるとと, ネズミの駆除効果など が実証された。更にハブの生息所を撤去改善する こととブロック摒やコンクリート㩳壁が，ハブの 防除効果に極めて有効であることが証明された。

以上の成績から, ハブ生息地域の集落内ハブ駆 除対策を進めるには，乙れらの方法を広く実施す るととが最む有効な方策であると考える。 


\author{
Symposium \\ Behavior and control of Habu, Trimeresurus \\ flavoviridis, a venomous snake
}

\title{
1 BEHAVIOR AND GONTROL OF HABU, Trimeresurus flavoviridis, A VENOMOUS SNAKE
}

\author{
Hiroshi TANaka \\ Department of Parasitology, Institute of Medical Science, The University of Tokyo
}

Behavioral studies of $\mathrm{Habu}$ were initiated more than 20 years ago in this country and monographs on this subject written by Takara or Koba and already been published in 1962. The contents of the study and researches on the fundamental and descriptive biology of Habu expanded to the population ecology and to the movement observed in the enclosure and in the field (Tanaka et al., 1967). The joint studies with various researchers started on the Amami Islands from the fiscal year (FY) 1970. Since FY 1977, systematic larger scale researches on behavior aiming at the control of Habu have been performed in Okinawa Prefecture and on the Amami Islands. The behavioral research on the particular species of venomous snakes must be unique in the world, and was highly evaluated at the International Seminar on Epidemiology and Treatment of Snakebite held at Naha in August 1980.

In the present symposium, results of the studies will be discussed by the main researchers on specific subjects. In addition to the topics to be presented a few remarkable findings are pointed out as follows;

The density of Habu in the field, measured by the catch curve method in 1970, demonstrated to be no more than $5 /$ ha and 3.16 on the average (Tanaka et al., 1974) but by the later studies, it should be corrected to be doubled. Out of many epidemiological analyses on the relationship between snakebite and environment, the number of snakebite in a village was well correlated with the area of actually cultivating field (Tanaka et al., 1978). Since this relationship may not be applied in Okinawa, more analyses based on the local conditions must be necessary. The population of Habu was larger in the area with larger population of field rats (Wada et al., 1981), and the snake population was reduced (Ikeda et al., 1971) by the control of rats. A possible constraint is the growth of rat population after a successful snake control. The relationship between both populations should be carefully studied further more.

Attractancy to Habu has been proven in live chickens in Okinawa and in live rats on the Amami Islands where the box trap with a live rat as bait was developed (Hayashi et al., 1979). The important subject of study will be to find out a chemical attractant, aside from the live baits, which will be screened from chemical samples by physiological and/or ecological assessments in the laboratory. 


\title{
2 A STUDY ON THE MOVEMENT OF HABU BY RADIO TRAGKING
}

\author{
Yoshitake Wada \\ Department of Parasitology, Tokyo Women's Medical College
}

In order to observe the movement of nocturnally active "Habu", Trimeresurus flavoviridis, miniature UHF transmitter and receiver were developed by Dr. Ikeda in 1970. Using this system, a total of $45 \mathrm{Habu}$ were released in the field from 1970 to 1979 , and their autonomous movement or reaction to the contact with man were observed. At first, the transmitter was implanted subcutaniously, and later, it was improved to attach on the body surface of Habu by adhasive plastic tape. Receiving the radio wave from $\mathrm{Habu}$, its direction was detected from two or more points at the same time and the position of $\mathrm{Habu}$ was decided on a map by triangulation.

The results of the studies were as follows:

1) Obviously, Habu was active nocturnally, but in some case, the snake showed almost no movement all through the night or Habu moved around in the daytime.

2) Usually, Habu moved not continuously through out the night. In many cases, cyclic activity was revealed: after 1-2 hours of movement, Habu stopped moving for $1-2$ hours.

3) The speed of movement measured by every 5-10 minute location was usually lower than 1 meter per minute and 3 meters per minute at its maximum.

4) The range of action of the male was larger than that of the female. Most of the female moved around within a small range of less than 30 meter diameter to and fro, but many males run straight and moved longer distance. The longest trip of 320 meters was recorded on a male during one night.

5) When the snake got into the water, it could go faster than on the land and the range of action tended to be wider.

6) Once Habu found some good place for the daytime rest, it stayed there in the daytime of the following few days. It appears that Habu might set up a "home range".

7) At the recapture of 29 released Habu, twelve of them were found in the space of ground, such as hole like the nest of rodent, the crevice in the ground and tree root or rock, and so on. And 11 snakes were found in the heavy thicket, 3 were under the pile of dead leaves.

The reactions to the contact with men at suger cane cropping:

1) When a man approached fast to $\mathrm{Habu}$, many $\mathrm{Habu}$ did not run or escape from him but were not found. Then a man passed through the site where a Habu was, and most of Habus held still at the site for 1-2 hours. Then the snakes moved and changed the site. It was thought that the Habu, pressed under the leaves of cane by the step of a man, took precautions with the posture of attack for 1-2 hours.

2) When croppers cut down the cane and approach slowly to Habu, many Habus 
can run away from men, especially in the warm season. In April, more than half of the snakes in the suger cane field had escaped from capture by the cropper.

\title{
3 DISTRIBUTION OF HABU (Trimeresurus flavoviridis) IN URBAN AND RURAL AREAS
}

\author{
Chokei Yoshida ${ }^{1}$ and Hiroyuki Akamine 2 \\ Okinawa Prefectural Institute of Public Health ${ }^{1}$ and Okinawa Public Health Association ${ }^{2}$
}

Aside from the countermeasures of first priority such as subjecting snake-bitten patients to well prepared anti-venom treatment, it is also considered a drastic measure of vital importance to isolate people from venomous snakes in terms of "artificial segregation of niche".

In Okinawa Prefecture, annual incidence of Habu-bites still remains higher than 200 and most of these cases occur in residential areas of rural and urban districts, where habitats of snakes overlaps those of man.

In order to get a modus operandi of circumscribing the habitats of $\mathrm{Habu}$ in certain municipal districts, thorough investigations were carried out at Naha City (principal city of Okinawa Prefecture-population; 300 thousands, area; $38 \mathrm{~km}^{2}$ ) and other two adjacent rural districts Nishihara and Sashiki.

Approximately $10 \%$ of all the households in Naha City and $30 \%$ in the other two towns were visited by well trained university gradualtes and questionairing were conducted on the adults with at least 5 year history of residence to gather informations about sighting snakes. Total numbers of sightings of Habus including eggs and sheddings in those municipalities were 2,265, 439 and 455 respectively, and were spotted on maps with a scale of 1 to 2,500 .

Demarcation of habitats or "dangerous areas" was made by circumscribing a closed shortest line arround the outermost spots of sightings which could be thought to share common eco-system to the adjacent green portion of land and by adding a surplus zone of $50 \mathrm{~m}$ width arround the closed line for the sake of safety. These habitats or "dangerous areas" were coloured green.

"Cautionary areas" coloured with yellow were set further $50 \mathrm{~m}$ outside of every one of the "dangerous area". All the rest of the municipal areas was coloured pink as non-habitat or "safe area".

Tricolour maps were thus made up as the result of demarcating the target areas of eradication of Habus, showing the dangerous areas with green, the cautionary areas with yellow and the safe areas with pink.

Approximately 100 thousands or $32.3 \%$ of the whole population of Naha City were found to live within the green "dangerous" areas, while in the other two towns 16 thousands or $83 \%$ (Nishihara), 6 thousands or $60 \%$ (Sashiki) live within the green areas which cover $91 \%$ and $81 \%$ of the whole municipal areas respectively. 
$98 \%$ of all the 1,189 points of sightings of Habus occurred within the distance of $30 \mathrm{~m}$ from the edge of woods and thickets in Naha City, whereas $95 \%$ were found not more than $50 \mathrm{~m}$ far from the edges of forests and grassy areas in the other two rural districts.

Interval time and distance between two sequent automobiles passing on the double-lane roads in Naha City, calculated from the data of traffic census, revealed that Habus could hardly sprawl from one thicket to another across a road in 27 seconds, the longest interval time at midnight (21:00-05:00) optimum for the activity of Habus.

In the rural district Sashiki, on the other hand, overall quadrates (net of $100 \mathrm{~m}$ meshes) revealed a significant negative correlation between the frequency of sighting Habus per household and the number of household in a quadrate ( $1 \mathrm{ha}$ ).

Judging from all these findings, it was concluded that Habus could hardly expand their habitats beyond the outskirt of a thicket on which they depend greatly. Motor traffic, housings and other human activities play an important role in dividing the original habitats of Habus into smaller ones giving a hint to us of the systematized partial eradication of Habus in these patchy habitats and of the procedures which lead to the goal of our "artificial segregation of niche". Questionairing was verified to be effective for the overall investigation on the distribution of Habus in rural and urban residential areas.

\title{
4 POPULATION STUDY AND EXPERIMENT OF EXTER- MINATION OF Trimeresurus flavoviridis IN MINNA ISLAND, OKINAWA
}

\author{
Seiki Katsuren and Chokei Yoshida \\ Okinawa Prefectural Institute of Public Health
}

This paper presents a prototype of eradication programme of one of the Okinawan venomous snakes Habu in a small island and the ecological features clarified by the operations carried out for five years since 1977 .

On the island Minna which resembles a horse-shoe extending $1 \mathrm{~km}$ in the distance across and has an area of 50 ha and an altitude of $12 \mathrm{~m}$ above sea level, there live approximately 50 people raising sweet potatoes, carrots, water-melons and cattles, etc. There inhabits no wild mammal such as mongoose, rat and mouse, etc. Habus were supposed to feed on birds, lizards and other small animals.

One hundred and eighty five traps were set on every center of quadrates ruled into $50 \mathrm{~m}$ covering all the land surface. Traps baited with live chickens (and mice later) captured 43 Habus (0.002/trap-day) in 1977, 37 (0.0013) in 1978, 43 (0.002) in $1979,41(0.0009)$ in 1980 and $20(0.0005)$ in 1981, all of them with the estimated age of more than 1 year. Sex, body length and weight, gastric contents of the captured were examined and their distribution in relation to the flora, atmospheric phenomena and other environmental conditions were discussed. 


\title{
5 PREVENTION OF INVASION OF THE SNAKE, HABU, Trimeresurus flavoviridis, USING AN ELECTRIC FENGE
}

\author{
Yoshiniro Hayashi \\ Department of Parasitology, Institute of Medical Science, The University of Tokyo
}

It is reported that more than $80 \%$ of $\mathrm{Habu}$-bite cases has occurred in agricultural field and in residential areas in the Amami Islands of Japan. Amami-oshima which is the biggest island having an area of $819 \mathrm{~km}^{2}$. Therefore, it seems difficult to control all the Habu from the island. However, it seems to be easy to remove Habu from the human habitation, which is less than $1 \%$ of the whole area of the island, after protecting human habitation from the invasion of Habu. To prevent the invasion of the snake, the experiment of the efficacy of the electric fence was carried out in this study.

It is widely known that the fence of $150 \mathrm{~cm}$ in height is needed to prevent the invasion of Habu. In this experiment using an open enclosure, however, it was found that the invasion of Habu was perfectly prevented by the electric fence of $65 \mathrm{~cm}$ in height; the highest current is $480 \mathrm{~mA}$ under $500 \mathrm{ohm}$ resistor, and the electric power is 5VA flowing intermittently. When the animals have high intelligence, e.g. wild boars, they can recognize the danger of the electric fence and never come up to the fence after suffering a single electric shock. In the case of Habu, however, it was observed that they did not stop the trial to climb the fence after suffering the shock.

To clarify the efficacy of the electric fence in the field, the fence of $1,000 \mathrm{~m}$ in length was constructed in Te-an Village (6.75 ha) in 1977. To compare the number of Habu observed before setting the fence, less than $50 \%$ of Habu was observed by the village people in 1980 .

The subsequent experiments are being carried out in three villages in Tokunoshima using the electric fence of more than $7,000 \mathrm{~m}$ in length.

\section{STUDY ON GONTROL OF HABU ON THE AMAMI ISLAND}

\author{
Shogi Mishima \\ Department of Medical Zoology, School of Medicine, Dokkyo University
}

It is reported that more than $55 \%$ of the Habu-bites occurred in the agricultural fields, whereas $25 \%$ occurred in residences. Thus it is important to decrease the number of bites in these area.

Since 1977, members of the Research Commettee for Studies on the Control of 
Habu in the Amami Islands (Chairman: Y. Sawai) engaged in the basic studies on ecology and the method to control Habu. From these studies, it has been elucidated that places where Habus appear frequently were around the stone fence which consisted of boundary between residences and banks. It was found that a net combined with electric fence were effective to prevent the invasion of Habu. Effectiveness of a trap with live rat as bait was also confirmed.

Based on these results, field trials were carried out at Tete and Todoroki area in 1980 and 1981 respectively. The results indicated that the electric fences encircled with the model areas were effective to prevent the invasion of $\mathrm{Habu}$ into villages, and Habu traps put along the fence were effective to collect Habus that run against the fence. It was also confirmed that removal of nests of Habu by substituting fence of stones or banks for fence of block or concrete is also effective to decrease the number of $\mathrm{Habu}$. 